\title{
The right to health in context of ensuring the best interests of the child
}

\author{
Inga Kudeikina and Karina Palkova
}

Rīga Stradiņš University, Latvia

\begin{abstract}
The right to health is one of the human fundamental rights. In present socio-legal area in health security issues, the human as an unconditional obedient patient, transforms into medical practitioner's associate, actively participating in all discussions of issues, which affect his health and executable medical manipulations. The human from medical object has turned into the medical subject. As exceptions can be mentioned persons who, for objective reasons, are not able to exercise their rights in full. One of such person group is children. Children have no capability to exercise their rights themselves. Therefore it is important to understand whether the volume of child's right is equal to the volume of adult's rights. Conditionally, we can say that in the stage of exercising the right, children depend on their representatives. The article will provide information on the issues, which affect child's right to health in context of ensuring the best interests of the child in Latvia according to the local and the European Union legal documents. In addition, the article will show the mechanism for dispute resolving, which may occur between a medical institution (doctor) and a person, who represents the child in Latvia. Both international and national legal acts stipulate that a child requires a special care, which includes ensuring the best interests of the child. It is essential that the concept "best interests of the child" is not defined in legislation and in all cases it is subject to interpretation of the adopter of the law (the user). On the fact, how fully the child's natural or legal guardians will defend the interests of the child, depends observation of the child's fundamental right - right to health. To find the answers to the current research questions descriptive, analytical, deduction-induction methods, etc. are used.
\end{abstract}

Key words: child's interests, health, right to health care.

\section{Objective and methodology of the thesis}

The objective of the work is to research the child's right to health in context of ensuring the best interests of the child, answering the question, what legal mechanisms shall be improved, to make the child's natural or legal guardians' action for defending the child's rights in compliance with the best interests of the child in Latvia.

In research descriptive, analytical and deduction-induction methods are used. Descriptive method is used to describe characteristics of a specific phenomenon of child's right to health in context of ensuring the best interests of the child. Analytical method first of all helps to determine and then evaluate the legal concept or the issue and content of the legal principles and norms.

Deduction-induction methods are used to find out the current problem from the more general to the more specific, and opposite - moving from specific observations to broader generalizations and theory. It helps to clarify the outcome of the research. 
In research, systematic review is used as well, including database search, management and acquisition of relevant literature, thematic and literature review. Under cover of these methods, legal acts, opinions of legal scientists are analysed and conclusions and suggestions are made.

\section{Child's right to health}

Health is one of the most important basic rights of every human being. The mentioned right is declared in a number of international acts. According to the World Health Organization preamble, the enjoyment of the highest attainable standard of health is one of the Fundamental rights of every human being without distinction of race, religion, political belief, economic or social condition [1].

The constitutions of the organization state that the right to health is fundamental. Article 25 of the Universal declaration of Human rights provides other definition of health importance. It states, that everyone has the right to a standard of living adequate for the health and well-being of himself and of his family, including medical care [2].

The right to health is also included in other international and national documents. The Article 111 of Constitution of the Republic of Latvia states that the state shall protect human health and guarantee the basic level of medical assistance for everyone [3]. In view of it, there are no indications that would specify and highlight minor right to health.

The regulation shows us that the right to health is unique and universal. On the other hand, Latvian national legislation provides regulation, which shows importance of the minor right to health [4]. The right to health inherently is social and economic.

This is illustrated, for example, in Protection of the Rights of the Child Law of the Republic of Latvia. Section 12 Social Rights of the Child. It says that a child has the right to free-of-charge health care, as determined by the State program. Section 13 Freedoms of the Child, states, that child has a right of association, insofar as it does not threaten the health and the life of the child.

Section 21 Limitations on the Rights of the Child, shows us how minor rights to health may be restricted. Section provides possibility make a limitation of minor rights to health in the interests of security and protection of a child himself/herself.

It should be noted, that minor rights are very wide due to multidisciplinary approach. The right to health and other minor rights are mentioned in many legal disciplines.

In addition, right to health is a human right, and cannot be divided by subjective signs. The age of a person is a subjective criterion and cannot be a reason to narrow the minor rights to health. It means that minor rights to health must be overviewed as subjective rights. In order to clarify the subjective and objective rights, many different definitions are applied. K. Deshler says that subjective rights give the opportunity to a person to enjoy the rights and to request from other person active reaction or abstain from it. Authors agreed on that view. From the author's point of view in legal theory subjective rights means an individual prerogative of a subject of rights [5]. As can be seen, minor rights are wide and should be overviewed as subjective rights. Obviously, minor patients have universal rights to health and nobody can restrict the rights. In addition, minor rights to health care are one of the most important human rights, and the situation when minor patients, due to their age, are restricted to decision-making process is not acceptable.

Children must have the right to participate in decision-making process in medical health care. To make this process more relevant, effective minors must have full information about the process. The level of the child's competence of the process is presumed from the age of five. Making a decision on child's treatment on their behalf, one must remember that parents 
and medical practitioners shall rather prove the child's incapability to judge objectively about the problem situation and a decision-making process [6].

\section{Provision of the child's best interests}

Studying the matter about the children's rights in health care, great attention shall be paid to the concept "the child's best interests". The matter of children's right in health care, its observation and realization is one of the most complicated issues in the field of Medical Law.

On the one hand, the local and international legal acts protect child's interests, stating the scope of this right, which must not be violated. On other hand, the legislation delegates the third parties to take care of observation and protection of children's rights.

The definition of the concept "the child's best interests" is not found in the legislation of the Republic of Latvia. The general principles only are mentioned, of which arises the understanding of the child's best interests. For example, the minimal warranties, therefore also child's interests are stated in the Constitution of the Republic of Latvia, in the Law of Protection of the Rights of the Child, Civil Law, etc.

Also international legal acts, for example, the United Nations Convention on the Rights of the Child (hereinafter - Convention) offer the range of children's rights, which strengthen the child's rights and human rights at the legislative level in general. The preamble of the Convention states that, considering the child's physiological characteristics, maturity level, he/she needs a special legal protection. The Convention explains the institute of the children's right on the merits, provides the unequivocal explanation of the meaning of children's rights.

In article 3.1. of the Convention it is determined that in all activities related to children, regardless of the state or municipal institution performing them, the attention primarily is paid to the providing of the child's best interests.

Essentially, the Convention provides universal principles in observation of the children's rights, paying special attention to the observation of the child's best interests. The term "the child's best interests" is widely debated and interpreted. From a practical point of view, the term "child's best interests" always is going to be unique and universal. The perception and understanding of explanation of the term will depend only on situation, where the mentioned universal rights will be reviewed.

The distinctness of uniqueness and understanding shall change depending on legal, social, economic or other context. However, studying the matter of the term "child's best interests", a scope of children's rights mentioned in the Convention shall be taken into account, especially focusing on the sustainability of these interests.

Reviewing the term "child's best interests" it should be understood that in the centre of the research there is one goal. This goal is to provide the child's happiness, physical and emotional protection, and their mental development. From one side, the child's best interests are the child's wellness, which is very wide and relative term. From the other side, the question arises how to evaluate the child's best interests and who has right to do so.

Defining the child's best interests, the ability to acquire education should be mentioned, as well as having their parents and being cared by parents, and having someone who would listen to them and talk to them if they have problems.

The actions, which are aimed at provision of the child's best interests, must have a primary meaning. From the mentioned above one can conclude that the meaning of the term "child's best interests" is very wide.

In provision of the child's best interests, it is impossible to identify objective factors. It means that relevant interests are only subjective and for their provision, primarily, situation 
assessment should be made through the prism of subjectivity, similar to the assessment of child's right to health care performed in this research.

Researching the explanation of the child's best interests, a question of legal characteristics arises, how to balance the basic elements of these rights. Therefore, depending on the situation, where child's legal interests are affected, one should understand the priority of child's best interests. Otherwise, there is a risk to create a situation, where child's rights will not be balanced, and therefore will be encumbered the observing of the child's best interests.

The Convention points to the range of rights, which must be applied regardless of the child's situation. Researching the goal of the Convention, one should point out its desire to pay a special attention to the child's rights in the context of human rights. At the same time the child's human right, arising from the legal scope provided in the Convention, is located in a close relationship with public and private sector. This correlation directly affects the observation of the child's, parents, or the guardian's right representing the child's interests.

In general, the child's rights mentioned above and their multi-functionality affect the provision volume of the child's best interests. While the mechanisms of provision of the child's best interests are applicable to persons, who represent the child's interests in a legal way in the fields of the law.

The best child's interests are a minimal standard usually used, for example, in family law. It shows the possibility to make decisions, which can influence child's interests in adoption cases, parents' divorce cases, etc. In that case, the best interests of the child should be taken into account, because every process may influence child's mental health.

Considering the stated in the research, the child's best interests are multidisciplinary, however they are not developed in all disciplines as good as in family law. Comparing to family law, the child's best interests are not protected enough in health law. Because of complicated approach to the definition of the "child's best interests" some difficulties regarding the child's interests representation are coming up.

It means that for health care cases, for example, legal guardians must define the best interests of the child in a wider way, but from the child's subjective criteria and perspective.

Researching the issue of the child's best interests it was detected that, in present, criteria, according to which the child's best interests could be assessed, have not been developed. Additionally, we should take into account that in the international legal acts basic principles are stated, which should be observed during evaluation of the volume of the child's best interests [7].

\section{Children and their legal guardian's competence for decision-making process in health care}

The Convention on the Rights of the Child states that there is a guarantee for every child from the point of view of human rights. It means that each child up to the age of 18 is protected under the Convention.

The discussion is about children's rights to participate in decisions related to health care. In authors opinion children's participation in this process is one of their fundamental rights.

Part I and II of the article [8] 177 of the Civil Law of the Republic of Latvia determines that before reaching the legal age, the child must be under the parental custody. The custody is the parents' right and obligation to take care of the child and his/her property, and to represent the child in his/her personal and property relations.

From the above mentioned it is concluded that the term of custody right is separated from the term of right to care. The child's care means the parents' right and obligations to maintain the child, namely, to take care of his food, clothing and also to provide the health care. 
Researching the issue of representation of minors and provision of their best interests, it is important to understand the extent to which the child's parents are authorised to perform appropriate actions, namely, the legal representation of the personal and property relations within the limits of right to care amount.

Part I of Article 21 of the Administrative Proceeding Law of the Republic of Latvia [9] determines that the procedural right of a person being under the age of 15 , or who has been recognized as incapable, shall be realized by this person's legal representative.

At the same time part II of the Law explains that, if the court considers that the interests of minor's legal representatives or legal representatives' and minor's interests are mutually different, it at its discretion requesting the opinion of the Orphan's Court, can determine other person as a minor person's representative. It can also request the Orphan's Court to appoint a special guardian for protection of the minor person discussing this person's right and interests in the specific matter.

Part III of Article 21 of the Administrative Proceeding Law determines that the procedural right of a person of the age 15-18 shall be realized by this person's legal representative. For such issues the institution or court shall ask the appropriate minor person to participate in proceeding.

Part I of Article 186 of the Civil Law provides that parents shall jointly represent the child in his/her personal or property relations (joint representation).

According to the mentioned Article 186 of the Civil Law, one of the parents can represent the child in his/her personal or property relations unilaterally, if the second parent has not reached the age of majority, has died, or if by an agreement or court judgment was founded one parent's separate custody. The exception are cases, when, according to the law, the child in his/her personal relations is represented by both parents.

At the same time, part IV of Article 186 of the Civil Law determines that the parent with limited legal capability shall represent a child in property relations in a volume, in which the court has not limited the parent's legal capability. Additionally, it is determined that each parent shall have right to perform legal actions, which are within child's interests, if with regard to the child there is a risk of adverse effects.

The aforementioned considerations show that legal representatives have not only wide scope of rights, but also a number of obligations to protect and represent the child's interests. It means that the child's legal representatives are obliged to provide observation of the child's rights and interests, including health care. However, it is important to identify the volume of rights of their legal representatives or parents, which would limit the child's own interests.

Making a decision, which affects child's best interests, the legal representatives should evaluate whether they are able to provide necessary conditions for child's full development, including the area of health care. Additionally, attention should be paid to the parents' subjective ability to make appropriate decision (personal characteristics, their ability to raise a child, understanding of parents' obligations, moral character, health condition and other possibilities). Also the child's subjective attitude towards parents (affection towards them, wish to live together with one or another of parents and other conditions) should be taken into account [10].

From the aforementioned it is concluded that in decision making by legal representatives on provision of the child's best interests health care is not only complicated but also a subjective process, whose precondition is a research of multiple family factors. The objectivity in the study of these is possible to provide neither by the Orphan's Court, nor by other institutions or family members.

The minor's competence in making decisions in health care means - "to have capacity" for decision-making. At the same time, big role is played by minor's competence to describe 
the problem appearing in case of health care [11]. Here should be mentioned the next problem of providing of the child's best interests from the side of legal representatives. We have to take into account the child's capability to argue with the legal representatives and defend his/her opinion on matters related to health care. The most important and difficult step in minors and their legal guardian's relations in decision-making process, related to medical health care, is the level of understanding between them. Parents always know the best way for their child. If in the family there is misunderstanding, lack of attention or love, the parent will never know about the real child's life and therefore particular decision will not be in the best interests of the child [12].

Considering the aforementioned, we should point out that the right to health is primary and exclusive. Therefore, it should be superior comparing to custody right. Child's right to health is primary also in such issues as parental decision related to child's treatment procedure. At present in Latvia the system, which would provide the protection of child's right in the field of health care should be improved, resolving disputes with a medical institution or a doctor. When a dispute between a medical institution (doctor) and a person who represents a child, occurs, there is no clear action model of the child's representatives or medical institutions (doctors). For example, which court the dispute on child's treatment procedure would be cognizable.

In 2013 in Latvia Medical Treatment Risk Fund was established. The aim of the fund is to provide opportunities for the patients to protect their rights and receive help outside the court [13]. It means that legal guardians in Latvia have the opportunity to address the issue of damages to health or life, done to their child during health care, to the administrative procedure. We have to take into account that the fund revises only disputes related to remuneration for the harm made to the person's health. The legislation of Latvia does not provide the settlement procedure of such disputes, which arise from a controversial decision about minor's treatment process or about provision of child's best interests in treatment procedure. Expressing so complicated matters that affect the observation of minors' rights and interests within the health care procedure, must be provided unequivocal resolving procedure of appropriate disputes, by applying in courts and requesting the Orphan's Court as a representative for defence of child's interests.

\section{Results}

As a result of research, the authors came to the following findings:

1. the right to health is universal and does not depend on the subjective characteristics of the legal subject, therefore the volume of child's right is equal to the volume of adult's rights;

2. the term "child's best interests" is very wide and has not been defined in legislation of Latvia, which has resulted in difficulties in their appliance, especially in health care;

3. the child's natural or legal guardians have wide rights to represent children and to act on their behalf, however persons, who represent children, shall make decisions on the basis of the child's, not their own interests;

4. the person's, who represents children, refusal of child's treatment is a denial of child's best interests and it shall be treated as a significant violence of child's right to health;

5. the mechanism for dispute resolving, which may occur between a medical institution (doctor) and a person who represents the child, is not provided. 


\section{Conclusions}

There is discernible legal competition between persons who represent children, custody right and child's right to health. The custody right provides the decision-making, however it is not always appropriate for the child's best interests. The child's natural or legal guardians may not agree to medical manipulations and in such cases there should be obligatory an assessment whether the refusal to collaborate with medical institution (doctor) is appropriate for the child's best interests. The right to health as a basic right prevails over the custody right, therefore disputes between the child's guardians and a medical institution (doctor) shall be revised in court, where as a child's representative shall be invited the Orphan's Court.

Additionally, the term "child's best interests" should not be understood as a general value, it should be determined in the Latvian Patients' Right Law.

At the same time, Latvian health care planning policy documents should be revised and supplemented, paying more attention to observation and provision of child's best interests in the health care procedure.

\section{References}

[1] Constitution of the world health organization (Last updated 2015, March 27). Access from http: //www. who. int/about/mission/en/ (2016, December 20)

[2] Universal Declaration of Human Rights, Access from http://www.un.org/en/ universal-declaration-human-rights/index.html (2017, January5)

[3] The Constitution of the Republic of Latvia, Access from: http://www.saeima.Iv/ en/legislation/constitution (2017, December 20)

[4] Protection of the Rights of the Child Law, http://likumi.lv/doc.php?id=49096

[5] N. Horns, Ievads tiesību zinātnē un tiesību filosofijā. Likums un Tiesības, nr. 3 (1999), p. 73

[6] J. Prince, J. McNeilly, Palliative Care for Children and Families: An Interdisciplinary (2009)

[7] Bāriņtiesas metodiskie norādījumi, Access from: http://www.bti.gov.lv/lat/ barintiesas/metodiskie_ieteikumi_/?doc=4063 (2016, December 10)

[8] Latvijas Republikas Civillikums, Access from: http://likumi.lv/doc.php? id $=225418$ (2016, November 15)

[9] Latvijas Administratīivā procesa likums, Access from: http://likumi.lv/doc. php?id=55567 (2016, November 11)

[10] Latvijas Republikas Augstākā tiesa Senāta Civillietu departaments “ Par tiesu praksi strīdu izskatīšanā par aizgādībās un saskarsmes tiesībām un uzturlīdzekļiem bērnam (2012), 36. lpp 